\title{
ESTIMATION OF MECHANICAL AND TECHNOLOGICAL SPECIFICATIONS OF MILK TRANSPORTING SYSTEM OF MILKING MACHINE
}

\author{
Oleksandr Medvedskyi ${ }^{1}$, Savelii Kukharets ${ }^{1}$, Jonas Cesna ${ }^{2}$, Vasyl Achkevych ${ }^{3}$ \\ ${ }^{1}$ Zhytomyr National Agroecological University, Ukraine; ${ }^{2}$ Vytautas Magnus University, Lithuania; \\ ${ }^{3}$ National University of Life and Environmental Sciences of Ukraine, Ukraine \\ aleksmedvedsky@gmail.com, saveliy_76@ukr.net, jonas.cesna@vdu.lt, achkevychv@gmail.com
}

\begin{abstract}
The constructional design of a milking cluster requires a scientific solution to some contradictive tasks. A rapid emptying of a milk chamber of the claw from milk provides a suitable background for a further process of the milk flow. Scientific works prove that excessive speed of a milk-air mixture in a long milk tube has some negative impact on milk quality. The scientists have determined some boundary conditions of milk transporting speed in a long milk tube. The influence pattern of mechanical and technological specifications of a milking claw on the flow speed in a long milk tube under condition of keeping the milk quality indices requires some scientific solution. The influence of the milk flow intensity, long milk tube diameter, as well as of the intensity of air delivery into the milk chamber of claw on the milk flow speed in a flexible milk tube has been proved. Under condition of invariant geometric parameters of a milk claw, the flow speed of milk increases in proportion to the milk flow intensity due to a higher pressure gradient. The regime of a milk-air mixture flow is characterized by a long milk tube diameter and by the geometric parameters of the throttle hole. The diameter and the length of a long milk tube determine the pressure drop of a transporting chain "claw-milking pipeline". The milk flow intensity has great influence on the pressure drop when transporting the milk portions to the milk transfer line. Under the condition of invariant long milk tube diameter, the pressure drop increases when the milk flow intensity grows. In the structure of pressure drops, the ones within the long milk tube length have the highest specific weight, and the supporting piers have the lowest losses. The optimal correlation between the parameter of the milk chamber of the claw, long milk tube diameter and the throttle hole diameter has been determined. It provides safe milk transporting irrespective of the milk flow intensity.
\end{abstract}

Keywords: milk flow intensity, milk chamber of claw, air delivery, pressure dynamics, milk quality.

\section{Introduction}

The design of the milking claw is characterised by its diversity. This is the result of a continuous search for its rational design and technological scheme. Most of the design concepts are directed at providing better conditions for milk transporting to the milk transfer line. As a rule, some positive result is achieved by a more sophisticated design of a claw or by an increase in air delivery.

The research [1] indicates a considerable milk dispersion caused by an intensive non controlled air flow into the milk chamber of the claw. During the transportation the milk is shaken up in the long milk tube, the milk fat particles remain on the long milk tube walls. As a result, $0.32 \%$ of milk fat is lost $[1 ; 2]$ that degrades the technological characteristics of milk. The reason for it is the parameter mismatch of the milk transporting unit from the claw to the milk transfer line.

The scientific research [3; 4] shows that under 8-10 liter milking, the diameter of a long milk tube must be in the range of 0.010-0.012 m. The research [5] analyzes the influence of air intensity on the optimal mode of milk transportation. The concept of "a coefficient of pressure changes" in a milk chamber of the claw has been introduced. Thus, the pressure coefficient while milking into a milk bucket must be equal to 0.86-0.92, and while milking into an upper milk pipeline the pressure coefficient must be 0.7-0.81. But a specific methodology of detecting pressure has not been given.

Some researchers [6] studied the influence of a milk chamber volume of the milking claw on providing stable pressure fluctuation for safe milk transportation. It has been determined that the minimal volume of a milk chamber of the claw must be $50-60 \mathrm{ml}$, in this way the optimal mode of movement of the milk-air mixture in a long milk tube will be kept. The research proves [7] that the reduction of the vacuum pressure fluctuation from 12 to $2.5 \mathrm{kPa}$ is observed in the milking clusters $130 \mathrm{ml}$ in volume. But when the milk flow intensity increases higher than $61 \cdot \mathrm{min}^{-1}$, the pressure drop increases up to $25 \mathrm{kPa}$, which is dangerous for cows health. Herewith, it is out of the question to make a vacuum "reserve".

The impact of a long milk tube diameter on the pressure drop during the milk-air mixture transportation was estimated. The researchers [8] point at the fact that vacuum fluctuation in the aspiration phase equals $9 \mathrm{kPa}$ in a system with a $11 \mathrm{~mm}$ long milk tube diameter and with the operating 
vacuum pressure of $44 \mathrm{kPa}$. In a system with $47 \mathrm{kPa}$ of the vacuum pressure and with a $12 \mathrm{~mm}$ long milk tube diameter, pressure fluctuations decrease to $6 \mathrm{kPa}$. The lowest pressure fluctuation, which is equal to $4 \mathrm{kP}$, is observed when the operating pressure is $44 \mathrm{kPa}$ and the diameter of a long milk tube is $12 \mathrm{~mm}$. Pressure fluctuation in a pressing phase up to $15 \mathrm{kPa}$ is observed in a system with vacuum equal to $47 \mathrm{kPa}$, when using a long milk tube $12 \mathrm{~mm}$ in the diameter. In a system with an operating vacuum of $44 \mathrm{kPa}$ and with a long milk tube diameter of $12 \mathrm{~mm}$, the pressure fluctuations are up to $10 \mathrm{kPa}$. These experiments prove the impact of a flexible long milk tube diameter on a milk transportation mode.

The issue on determining the rational correlation between the design of a milk chamber of the claw, the transporting system and the level of a vacuum pressure has not been solved yet. The intensity of air supply into the milk chamber of the claw on the milk flow intensity is to be arranged. Herewith, it is necessary to focus on a safe mode of milk transportation ensuring its qualitative indices.

Despite the knowledge-intensive research, the issue on determining the rational design parameters, as well as on the operation modes of a transporting system "milk chamber of claw - milk transfer line" is a topical scientific problem.

\section{Materials and methods}

The target setting is focused on milk quality improvement by means of its safe transportation by a milk transporting system of a milking machine. That is why it is necessary to determine the impact of the design parameters of a transporting unit of a milking machine on the milk transportation mode to the upper milk pipeline.

The methods of theoretic research are based on using the theory of math modeling, while using the main provisions of integral and differential measurements, hydro and gas dynamics, heat technology, vacuum technology (methods of classical sciences). The processing of the research results was based on using the provisions of the theory of probability and of the math statistics, the package of applied programs Statistica 10 and Microsoft Excel 2010. The research objects are the design and technological parameters of a milk chamber of the claw, as well as of a long milk tube when supplying milk to the upper milk transfer line.

The paper [9] suggests delivering air into the milk chamber of the claw during the pressing phase through the throttle hole under the distributing chamber pressure of the claw. It creates an additional pressure gradient that will improve the conditions of milk transportation, as well as of full milk chamber emptying. Herewith, the issue concerning the impact of vacuum pressure dynamics during the pressing phase on the mode of milk transportation by a flexible long milk tube remains unsolved.

Milk transportation to the upper milk transfer line by a long milk tube occurs under condition

$$
p_{m k} \geq p_{m p}+\Delta p_{p l},
$$

where $p_{m k}-$ pressure in a milk chamber of claw in a pressing phase, $\mathrm{kPa}$;

$p_{m p}$ - pressure in a milk pipeline, $\mathrm{kPa}$;

$\Delta p_{p l}-$ pressure drop in a long milk tube, $\mathrm{kPa}$.

During the pressing phase, pressure in a milk chamber is formed by partial pressures of completing the aspiration phase and by the pressure of the air volume, which comes from distributing chamber of a the claw. With due regards to the research [9] and [10], according to Klaiperon equation of gas state [11], the following equation is received:

$$
p_{m k}=\frac{p_{k} V_{k}+p_{d}\left(Q_{r} t_{c}\right)}{4 V_{k m}+\pi d_{p}^{2}\left(l_{p}-h_{m k}\right)},
$$

where $p_{d}$ - pressure in a distributing chamber of a claw, $\mathrm{kPa}$;

$p_{k}$ - pressure in a milk chamber of claw, $\mathrm{kPa}$;

$V_{k}$ - free from milk volume in a milk chamber under pressure $p_{k}, \mathrm{~m}^{3}$;

$Q_{r}-$ intensity of air supply into the milk chamber, $\mathrm{m}^{3} \cdot \mathrm{s}^{-1}$;

$t_{c}$ - duration of a pressing phase, $\mathrm{s}$;

$V_{k m}$ - constructional volume of a milk chamber of claw, $\mathrm{m}^{3}$; 
$d_{p}$ - long milk tube diameter, $\mathrm{m}$;

$l_{p}$ - long milk tube length, $\mathrm{m}$;

$h_{m k}-$ height of a milk portion in a long milk tube, $\mathrm{m}$.

The design and technological parameters of the claw and a long milk tube (Fig. 1) have influence on the vacuum pressure in the milk chamber during the pressing phase.

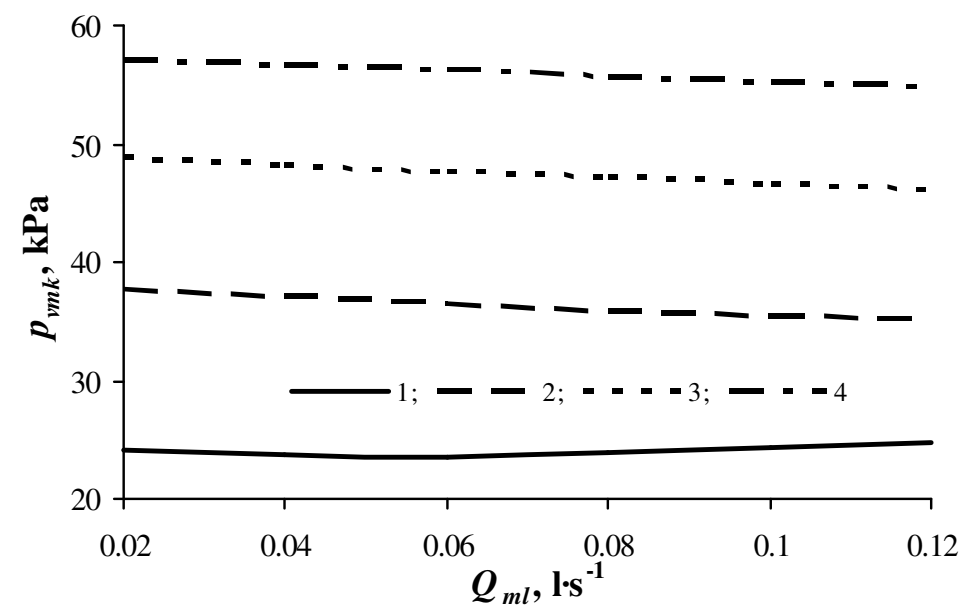

Fig. 1. Vacuum pressure $p_{v m k}$ in the milk chamber of claw during the pressing phase under milk flow intensity $\boldsymbol{Q}_{\boldsymbol{m} l}$ and diameter of the long milk tube $\left(\boldsymbol{d}_{\boldsymbol{p}}\right): 1-d_{p}=0.010 \mathrm{~m}$; $2-d_{p}=0.012 \mathrm{~m} ; 3-d_{p}=0.014 \mathrm{~m} ; 4-d_{p}=0.016 \mathrm{~m}$ (authors' research)

The diameter of a long milk tube has a considerable influence on the vacuum pressure level in a milk chamber of claw (Fig. 1). It happens because of some change in the total volume of a system "claw - long milk tube", irrespective of the milk flow intensity. The greater diameter of a long milk tube $\left(d_{p}\right)$ corresponds to lower pressure drop $\left(\Delta p_{p l}\right)$ during milk transportation to the milk pipeline. The milk flow intensity $\left(Q_{m l}\right)$ does not have a considerable influence on the change of the vacuum pressure level within the given diameter of a long milk tube. When the diameter of a long milk tube is 16$12 \mathrm{~mm}$, the vacuum level insignificantly falls down, and the milk flow intensity increases, except when $-d_{p}=10 \mathrm{~mm}$.

The diameter of a long milk tube is determined on the basis of the research [9] and of the recommended practice [8] (Fig. 2).

$$
d_{d}=1.128 \sqrt{\frac{\left(S_{t h} v_{t h} t_{\mathrm{c}}+Q_{m l} t_{s}\right)}{\left(t_{\mathrm{c}}+t_{s}\right) v_{m x}}},
$$

where $S_{t h}-$ cross-section area of a throttle hole, $\mathrm{m}^{2}$;

$t_{s}$ - duration of aspiration phase, $\mathrm{s}$;

$v_{t h}-$ motion speed of air in the exit area of a throttle hole with a fixed diameter, $\mathrm{m} \cdot \mathrm{s}^{-1}$;

$v_{m x}-$ recommended [8] motion speed of two-phase mixture of milk and air through the long milk tube, $\mathrm{m} \cdot \mathrm{s}^{-1}$.

The restriction of boundary speed of the milk-air mixture is caused by a necessity to maintain the qualitative characteristics of milk during its transportation to the milk pipeline. The long milk tube diameter is determined under the condition of milk flow intensity $Q_{m}=61 \cdot \mathrm{min}^{-1}$ for a milking machine of pair-wise milking.

The bigger diameter of the throttle hole (Fig. 2) corresponds to a bigger diameter of a long milk tube, irrespective of the motion speed of the milk-air mixture. It can be explained by the necessity to maintain the given milk flow motion speed by changing the coefficient of free space air saturation in a flexible long milk tube. 


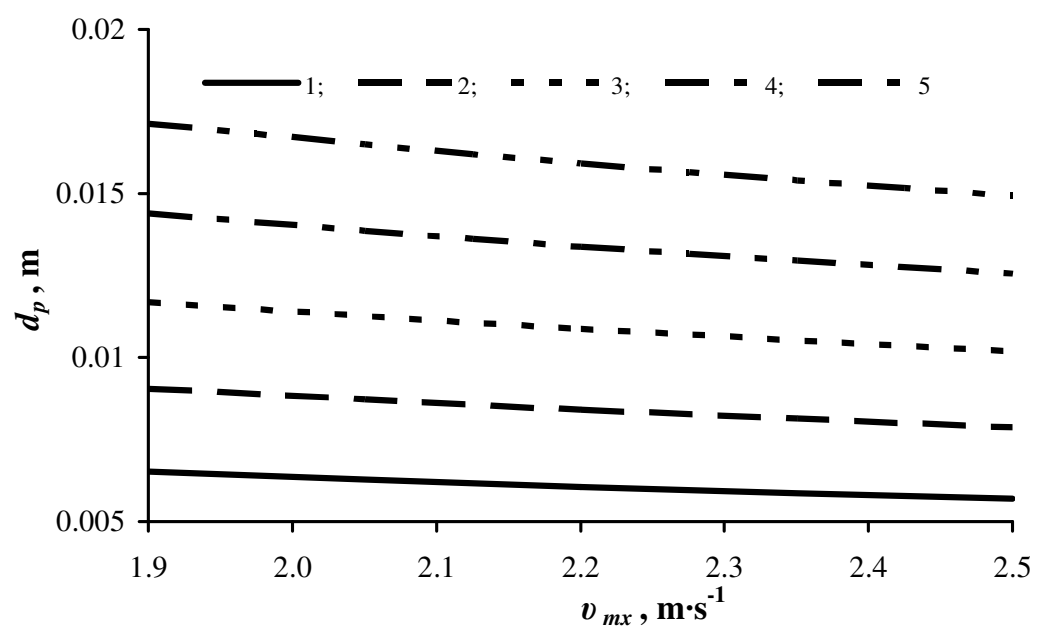

Fig. 2. Dependence of a long milk tube diameter $\left(d_{p}\right)$ from the motion speed of the milk - air mixture $\left(v_{m x}\right)$ and from the throttle hole diameter $\boldsymbol{d}_{t h}: 1-1.0 \mathrm{~mm} ; 2-1.5 \mathrm{~mm} ; 3-2.0 \mathrm{~mm}$; $4-2.5 \mathrm{~mm} ; 5-3.0 \mathrm{~mm}$ (authors' research)

\section{Results and discussion}

While simulating the impact of the design parameters of a cluster, as well as of a long milk tube on safe milk transportation, it is necessary to keep in mind some suppositions. The first one is a bound permissible intensity of air delivery under condition of maintaining the milk quality [3]. Herewith, the condition for the guaranteed milk transportation through the long milk tube to the upper milk pipeline looks like.

$$
\frac{p_{v m k}}{p_{l p}} \leq 1,
$$

where $p_{l p}$ - bound permissible vacuum pressure corresponding to the equation (1), $\mathrm{kPa}$.

Statement (4) is expressed by $k_{p}$ - the coefficient of correspondence of the vacuum pressure in a milk chamber to its bound permissible level (Fig. 3).

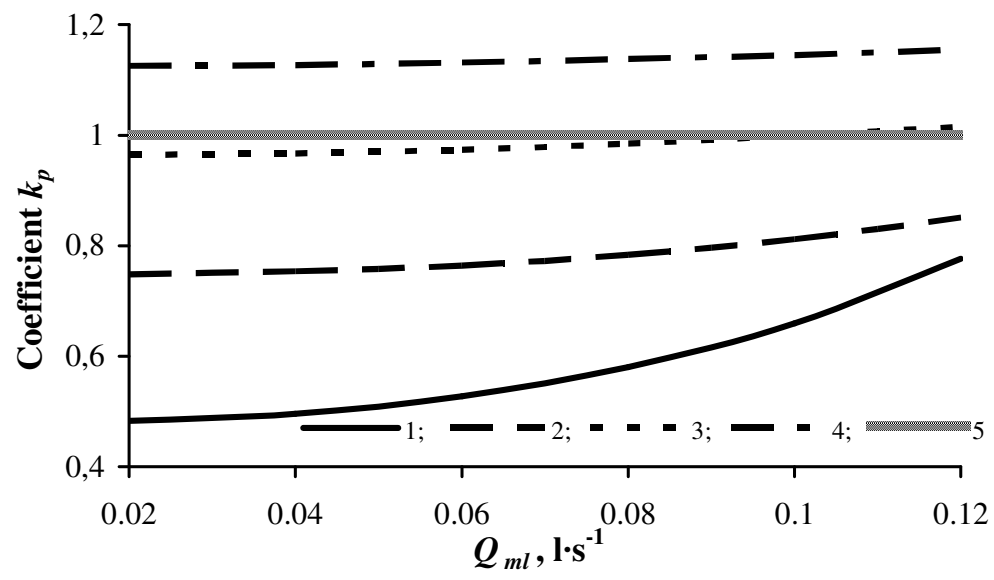

Fig. 3. Dependence of the coefficient of pressure correspondence $\left(k_{p}\right)$ from the milk flow intensity $\left(Q_{m l}\right)$, when the long milk tube diameter is $\boldsymbol{d}_{p}: 1-d_{d}=0.010 \mathrm{~m} ; 2-d_{p}=0.012 \mathrm{~m} ; 3-d_{p}=0.014 \mathrm{~m}$; $4-d_{p}=0.016 \mathrm{~m} ; 5-k_{p}=1$ (authors' research)

According to Fig. 3, the statement (4) is not true for a long milk tube $d_{p}=16 \mathrm{~mm}$ in diameter in the given range of milk flow intensity. When the milk flow intensity is higher than $Q_{m l}=0.101 \cdot \mathrm{s}^{-1}$, the statement (4) is not true for a long milk tube $d_{p}=14 \mathrm{~mm}$ in diameter. 
When the diameter of a long milk tube increases, the space free from milk increases as well. That is why to maintain the conditions for supporting stable pressure falls between the milk and the distributing chambers of a claw it is necessary to increase the air delivery intensity. It can be achieved, when the cross section area of a throttle hole increases (Fig. 4).

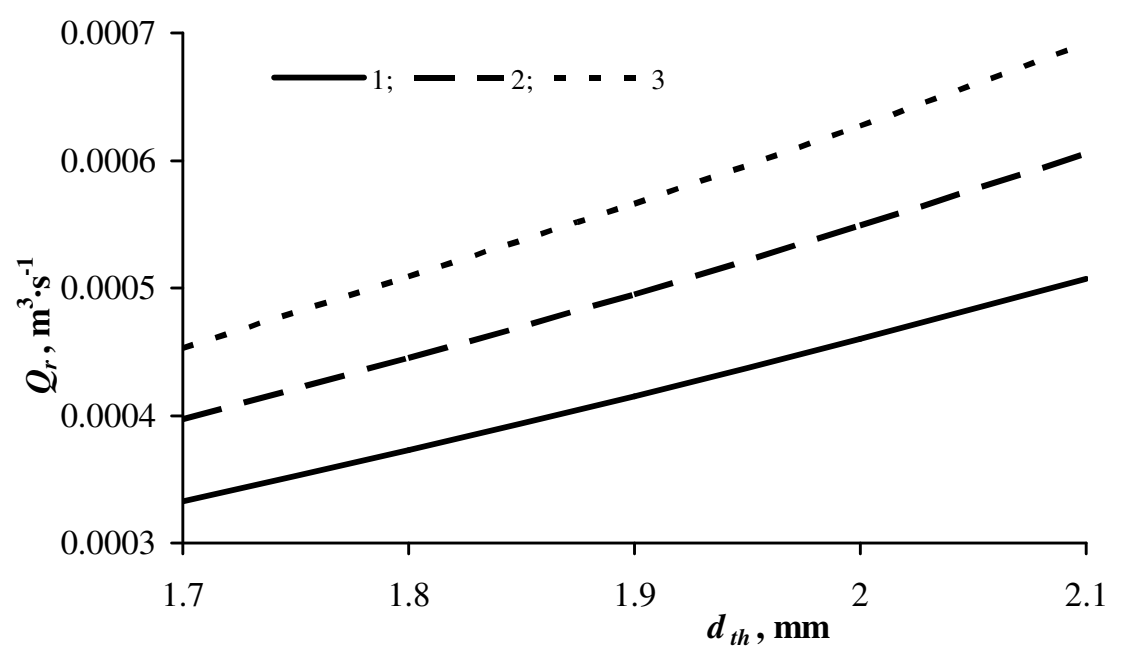

Fig. 4. Intensity of air delivery $\left(Q_{r}\right)$ into the milk chamber depending on the diameter of a throttle hole $\left(d_{t h}\right)$ when $Q_{m l}=6 \mathrm{l} \cdot \mathrm{min}^{-1}$ with the long milk tube diameter $\boldsymbol{d}_{p}: 1-d_{p}=0.010 \mathrm{~m} ; 2-d_{p}=$ $0.012 \mathrm{~m} ; 3-d_{p}=0.014 \mathrm{~m}$ (authors' research)

Higher intensity of air delivery into the milk chamber of the claw corresponds to a bigger diameter of the flexible long milk tube (Fig. 4).Within a stable diameter of a throttle hole the intensity of air delivery increases by $27 \%$, when the long milk tube diameter increases from 10 to $14 \mathrm{~mm}$. It is caused by the necessity to provide a proper pressure gradient for guaranteed milk transportation and maintaining its quality.

The experimental research was conducted under a determined intensity of the milk flow, which was fixed with a rotameter TW-300 type. The level of the vacuum pressure in the distributing chamber and in the milk chamber of the claw was determined by means of membrane tensometric suppliers IPD-2-0.06. The signal from the suppliers came through the comparison element, as well as through the intensifier TOPAZ 3-0.2 to the self-recording device H 3021-3 type. The received information was fixed and processed by the package of application software Statistica 10 та Microsoft Excel 2010.

Regression equation of vacuum pressure dynamics in the milk chamber of the claw during the pressing phase was received basing on the research findings:

$$
p_{v m k}=142.19+8.4 d_{t h}-27.1 d_{p}-0.99 d_{t h} d_{p}-21.3 Q_{m l} d_{p}+1.51 d_{p}^{2} .
$$

The adequacy of the received model (5) was estimated having a fiducially probability level $P=0.9$ under the calculated value of the Fisher criteria $F=7.9$. The coefficient of multiple determination equals $D=0.917$. The coefficient of multiple correlation equals $R=0.998$ (Fig. 5).

Graphic dependences (Fig. 5) point at the decrease in the vacuum pressure level in the milk chamber of the claw, when the diameter of the throttle hole increases within the fixed diameter of the long milk tube. In the given case, bigger diameter of a long milk tube corresponds to a higher level of partial pressure of the milk chamber of claw. It happens because of the increase of free from milk space under stable milk flow intensity.

When the milk flow intensity increases, the level of the vacuum pressure decreases, irrespective of the long milk tube diameter. It can be explained by the reduction of the total volume of the system "claw-milk pipeline" by increasing the amount of milk in the flexible long milk tube. The dependences of the parameters of the milk flow intensity, which are under studying, are of analogical character. 


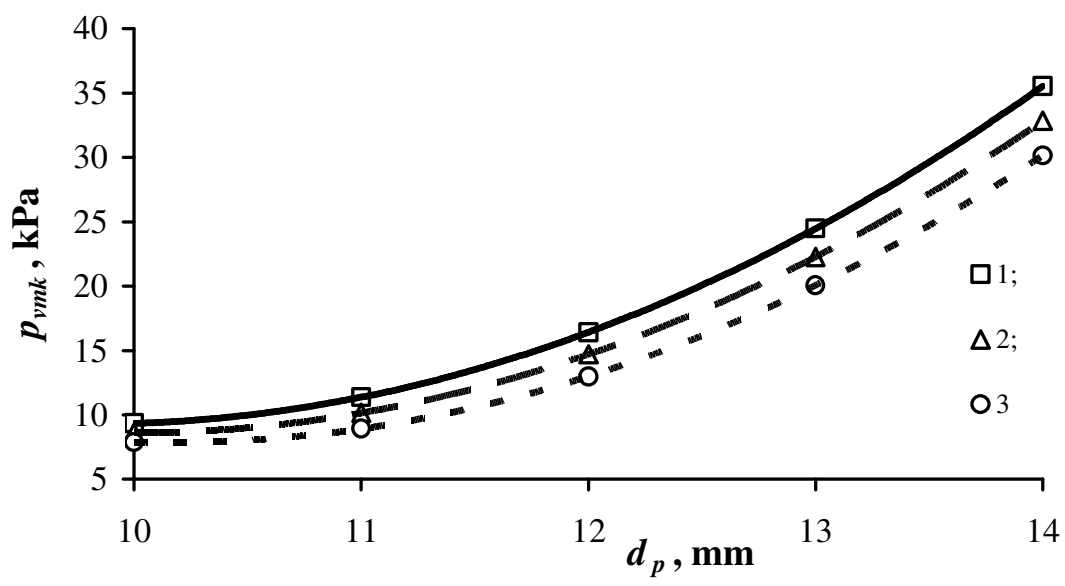

Fig. 5. Dependence of the vacuum pressure $p_{v m k}$ in a milk chamber of claw during the pressing phase, when the milk flow intensity is $Q_{m l}=6 \mathrm{l} \cdot \mathrm{min}^{-1}$ and the throttle hole diameter is $\left(\boldsymbol{d}_{t h}\right): 1-1.5 \mathrm{~mm} ; 2-2.0 \mathrm{~mm} ; 3-2.5 \mathrm{~mm}$ (authors' research)

A comparative estimation of the milk, received by means of the experimental milking machine, was made by an analiser Ekomilk KAM 98-2A. The research findings indicate the decrease in the level of fatty particle destabilisation by $11.1 \%$ as compared to production pipeline of milk.

\section{Conclusions}

1. Structural and technological parameters of a milk chamber of a claw, as well as of a long milk tube have a significant impact on the milk transportation mode to the milk pipeline. The necessity to correspond the air supply intensity into the milk chamber depending on the milk flow intensity has been proved. The determination of rational parameters and operating modes of the transporting system "claw-milk pipeline" will influence the improvement of milk quality.

2. Potential cases of non-compliance with conditions of guaranteed milk transportation to the upper milk pipeline have been determined. When the throttle hole $1,5-1,6 \mathrm{~mm}$ in diameter is connected with a long milk tube 14 and $16 \mathrm{~mm}$ in diameter, as the coefficient is $k_{p}>1$, the condition of guaranteed milk transportation is not fulfilled, when a long milk tube $10-12 \mathrm{~mm}$ in diameter is connected with a throttle hole $2.1 \mathrm{~mm}$ in diameter. Excessive air delivery through the throttle hole $2.5 \mathrm{~mm}$ in diameter does not provide a safe regime of milk transportation irrespective of the long milk tube diameter. A sufficient pressure gradient under condition of high milk flow intensity is not provided under condition of using the throttle hole less than $1.5 \mathrm{~mm}$ in diameter.

3. The research findings point at a rational connection of a throttle hole $2 \mathrm{~mm}$ in diameter and a long milk tube $12 \mathrm{~mm}$ in diameter. Under such parameters of a transporting system, safe milk transportation to the milk pipeline can be provided. A reduced level of milk fatty particles destabilisation by $11.1 \%$, as compared to the production pipeline of milk, confirms it.

\section{References}

[1] Палій А. П. Вплив молокопровідних систем доїльних установок на споживчі показники молока (Influence milking system of milking plants on consumer indicators of milk). Тваринництво України, 2016, vol. 9, pp. 20-22. (In Ukrainian).

[2] Besier J., Bruckmaier R. Vacuum levels and milk-flow-dependent vacuum drops affect machine milking performance and teat condition in dairy cows. Journal of Dairy Science, 2016, vol. 99, pp. 3096-3102. DOI: 10.3168/jds.2015-10340.

[3] Фененко А. I. Механізація доїння корів. Теорія і практика : монографія. (Mechanization of milking cows. Theory and practice : monograph). Київ, 2008. 198 с. (In Ukrainian).

[4] Besier J., Lindb O., Bruckmaier R. Dynamics of teat-end vacuum during machine milking: types, causes and impacts on teat condition and udder health - a literature review. Journal of Applied Animal Research, 2016, vol. 44, pp. 263-272. DOI: 10.1080/09712119.2015.1031780. 
[5] Upton J., Penry J., Rasmussen M., Thompson P., Reinemann D. Effect of pulsation rest phase duration on teat end congestion. Journal of Dairy Science, 2016, vol. 99, pp. 3958-3965. DOI: 10.3168/jds.2015-10466.

[6] Bluemel, F. E., E. Savary, P., E. Schick M. Effects of an extended c-phase on vacuum conditions in the milking cluster. Biosystems Engineering, 2016, vol. 148, pp.68-75. DOI: 10.1016/j.biosystemseng.2016.04.004.

[7] Павленко С. І., Алієв Е. Б., Лінник Ю. О. Методика експериментальних досліджень процесу переміщення молокоповітряної суміші в доїльному апараті. (The method of experimental studies of the process of movement of milk and air mixture in the milking machine). Науковий вісник Таврійського державного агротехнологічного університету, 2015, vol. 5, pp. 167-172 (In Ukrainian).

[8] Фененко А. И. Биотехническая система производства молока. Теория и практика : монографія. (Biotechnical system of milk production. Theory and practice : monograph). Нежин, 2014. 192 c. (In Russian).

[9] Golub G., Medvedskyi O., Achkevych V., Achkevych O. Establishing rational structuraltechnological parameters of the milking machine collector. Eastern-European Journal of Enterprise Technologies, 2018, vol. 91, pp. 12-17. DOI: 10.15587/1729-4061.2018.121537.

[10] Medvedskyi O., Kukharets S., Golub G., Dmytriv V. Installation of equilibrium pressure of milking machine vacuum system. 17-th International Scientific Conference Engineering for Rural Development : conference proceedings, 23-25 may 2018. - Jelgava : Latvia University of Life Sciences and Technologies, 2018, vol. 17, pp. 143-148. DOI: 10.22616/ERDev2018.17.N173.

[11] Лойцянский Л. Г. Механика жидкости и газа. (Mechanics of liquid and gas). Москва: Дрофа, 2003. 840 c. (In Russian). 